\title{
Villet egenskade, parasuicid eller selvmordsforsøk?
}

\author{
Ved Øivind Ekeberg
}

Selvmordsatferd kan være vanskelig å forstå, både med hensyn til begreper og atferd. Retterstøl har gitt en god definisjon av selvmord: "Ved selvmord forstår vi en bevisst og villet handling, som individet har foretatt for å skade seg selv, og hvor skaden har ført til døden" (Retterstøl 1995). Som det fremgår dreier det seg om både

Selv om definisjonen for så vidt er grei, er det noen ganger vanskelig å vurdere om et dødsfall er et selvmord eller ikke. Problemet er først og fremst at det kan være vanskelig å vurdere intensjonen. $H$ vis selvmordet var varslet, eller det foreligger avskjedsbrev er intensjonen klar, men oftest må intensjonen vurderes på bakgrunn av handlingen. Denne kan være så entydig at den reiser liten tvil, slik som ved skyting eller hengning. Ved dødsfall som følge av forgiftning er det ofte vanskeligere å vurdere om det heller kan ha vært en ulykke.

Det foreligger vanligvis en betydelig ambivalens ved sel vmordsatferd, og derfor kan intensjonen variere. $\mathrm{H}$ vis det benyttes brå metoder som skyting, behøver ikke intensjonen om å dø vare lenge. D et er tilstrekkelig med dødelig motiv i øyeblikket og tilgjengelig metode. Ved forgiftningsdødर्sall må intensjonen vare lenger, slik at ikke vedkommen de kan ombestemme seg og bli reddet.

D et er i praksis vanskeligere å vurdere selvmordsintensjonen hvis det dreier seg om selvdestruktiv atferd som ikke fører til døden. D ette kan synes paradoksalt, siden man har mulighet til å snakke med den aktuelle personen. Problemet er særlig forbundet med ambivalensen og den skiften de intensjonen. I mange tilfeller kan dødsønsket være sterkt til stede når midler inntas, men etter noe tid kan livsønsket ta over. H vordan skal man klassifisere en person som tar 20 tabletter Valium og som opplever dette som et selvmordsforsøk, men som ringer etter legevakt etter 10 minutter? H vor går grensen med hensyn til varighet av intensjonen eller hvor skadelig det aktuelle middel er før man kan klassifisere noe som et selvmordsforsøk?

\section{Selvmordsforsøk}

Det er ikke overrasken de at det også er flere og mer uklare definisjoner av selvmordsforsøk enn av selvmord. R etterstøl gir som definisjon på selvmordsforsøk:
"Ved selvmordsforsøk forstår vi en bevisst og villet handling som individet har foretatt for å skade seg selv, og som individet ikke kunne være helt sikker på å overleve, men hvor skaden ikke har ført til døden" (Retterstøl 1995.)

\section{Parasuicid}

Begrepet parasuicid ble introdusert av Kreitman og medarbeidere i 1969. Begrunnelsen for det var at selvmordsforsøk var en utilfredsstillen de betegnelse, fordi de fleste hen delser som ble beskrevet som dette, ganske enkelt ikke var det. De mente også at begreper som villet forgiftning eller skade heller ikke var dekkende, fordi de ikke la nok vekt på den nære sammenhengen mellom selvmordsforsøk og fullbyrdet selvmord, både knyttet til gjentagelse og det faktum at det i mange tilfeller var tilfeldigheter som avgjorde om en person overlevde eller ikke. Kreitman og medarbeidere foreslo derfor følgende definisjon på begrepet parasuicid:

"en handling som ligner på selvmord, men som er noe annet enn selvmord". $\mathrm{H}$ awton og Catalan kritiserte dette, fordi begrepet forutsatte en intensjon om selvmord som ikke behøver å være til stede (H awton \& C atalan 1987). En definisjon som legger til grunn at begrepet skal ligne på noe, blir nødvendigvis upresis.

Platt og medarbeidere utviklet så en definisjon hvor parasuicid og selvmordsforsøk likestilles: "En ikke vanemessig handling med ikke dødelig utgang, som er initiert av individet selv i forventning om slik utgang ( altså ikke dødelig utgang), som forårsaker skade på en selv, eller som uten inngripen fra andre ville gjøre det, eller som består i å tilføre seg et medikament eller et stoff utover den dosen som er anerkjent som den terapeutiske, og der utgangen av vedkommende selv blir oppfattet avgjørende for å frembringe forandringer i forventningene og/eller i sosiale forhold" (Platt et al. 1992). Dette er den definisjon som anvendesav W HO i dag. Det er imidlertid en lang definisjon med mange begreper som kan forstås på for-skjellige måter. Selv om det kan virke pragmatisk å likestille begrepene para- suicid og selvmordforsøk, er det lett å se at mange tilfeller som tilfredsstiller definisjonen av parasuicid, ikke dreier seg om noe egentlig selvmordsforsøk. Det er klart at det er stor forskjell på å ta noe mer medikamenter enn det som er vanlig i den hensikt å frembringe forandringer personlig, familiært eller sosialt og å hoppe ut fra 8 meter og allikevel overleve.

Etter min mening er Retterstøls definisjon av selvmordsforsøk bedre. I praksis vil imidlertid ikke denne definisjonen omfatte flesteparten av de selvpåførte forgiftninger som kommer til medisinsk behandling, og heller ikke de fleste tilfeller av kutt, tilstander som altså kunne klassifiseres som parasuicid.

\section{Villet egenskade}

ICD-10 benytter betegnelsen villet egenskade. $\mathrm{H}$ er er det igjen tale om intensjon og handling. En fordel med dette begrepet er at det stort sett dekker det som det lover. Det sier noe om at intensjonen var å skade seg selv og at det fant sted en selvdestruktiv handling.

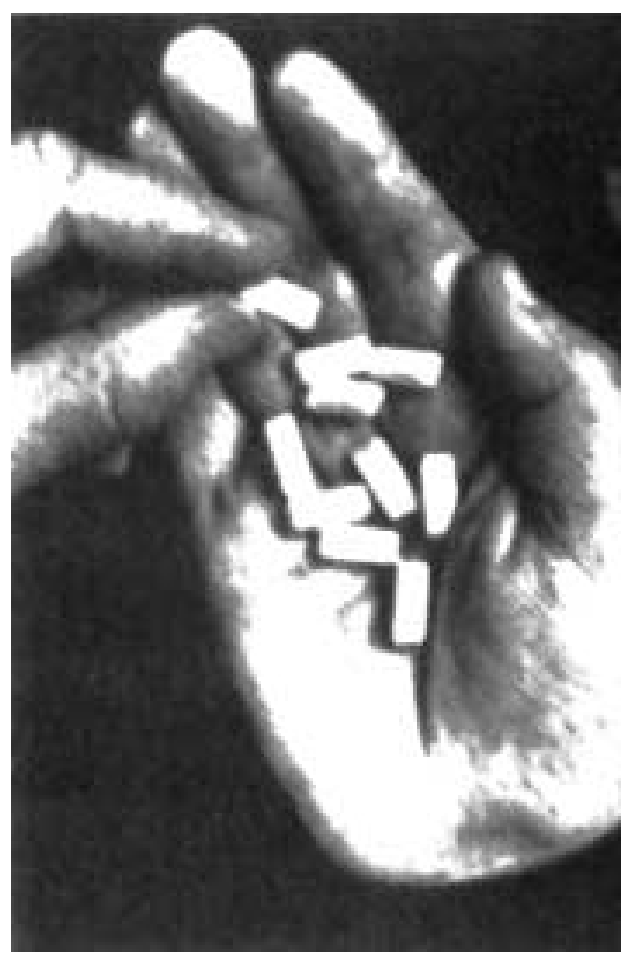


Betegnelsen forsøker ikke å skille mellom selvmordsforsøk eller ikke, eller inkludere begge disse mulighetene. A v samme grunn blir informasjonen begrenset. Derfor er det av mange grunner nødvendig med en nærmere presisering av både handling og intensjon. M ed hensyn til handlingen bør det fremgå om det dreier seg om forgiftning, kutting eller annet. I tillegg bør det foretas en inndeling med hensyn til intensjonen, altså om handlingen skal oppfattes som selvmordsforsøk eller ikke. Det er viktig å huske på at suicidalintensjon er en dimensjonal, ikke-kategorisk størrel se.

Ved U llevål sykehus har vi i mange år først og fremst klassifisert selvdestruktive handlinger $\mathrm{i}$ henhold til handling, og deretter i henhold til intensjon. De fleste tilfellene dreier seg om selvpåført forgiftning. Basert på intervjuer og øvrig atferd vurderes det så om handlingen var uttrykk for selvmordsforsøk eller var appell preget. $\mathrm{H}$ er er det både tale om å høre pasientens beskrivelse og å foreta en klinisk vurdering. $M$ ange pasienter sier at de ønsket å ta sitt liv da de tok tabletter. I mange tilfeller kan de ha tatt større doser tidligere, de kan ha andre til stede som vil sikre rask behandling, eller de kan selv ta kontakt med noen som kan hjelpe. Det er også mange som etter noe tid erkjenner at de innerst inne verken ønsket eller trodde at de ville $d \emptyset$ av overdosen. I kke minst blant unge mennesker kan det være betydelig forskjell på angivel se av selvmordsintensjon og den faktiske risiko. Rossow \& Wickstrøm (1994) fant at 8,3\% av ungdommene i N orge oppga at de en eller annen gang hadde forsøkt å ta sitt eget liv. Ved å spørre på en litt annen måte, slik at spørsmålet om vedkommende virkelig ville dø kommer tydeligere frem, blir prosenten betydelig lavere. Endelig er det en betydelig inkonsistensi svar om selvmordsforsøk. Det er ikke uvanlig at en som har tatt en overdose, på det samme spørreskjemaet kan skrive at hensikten var å dø, men som tre linjer senere krysser av for at hensikten var å få hjelp. Det er heller ikke uvanlig at en som på et tidspunkt rapporterer å ha forsøkt å ta sitt liv, noe tid senere svarer nei på det samme spørsmålet.

I et forgiftningsmateriale fra 0 slo i 1980 var det såledesikke mer enn $17 \%$ av for- giftningene som ble vurdert som selvmords forsøk, mens de fleste ble oppfattet som rop om hjelp (Jacobsen et al. 1984).

Pasientene selv oppga noe oftere at de ønsket å dø, men de var allikevel mer eller mindre klar over at de ville overleve. Den kliniske nytten av en slik inndeling viste seg ved etterundersøkelse etter 10 år. De som ble vurdert som alvorlige selvmordsforsøk, hadde dobbelt så stor risiko for selvmord i oppfølgingstiden, når det var korrigert for andre risikofaktorer (Ekeberg et al. 1994). Den totale dødeligheten var omtrent like stor i begge grupper, og betydelig høyere enn forventet. For dem som ikke ble vurdert som selvmordsforsøk, var imidlertid dødsårsakene oftere ulykker eller rusrelatert. Selvpåført forgiftning som uttrykk for villet egen skade er således en meget viktig risikofaktor for senere død.

Som konklusjon mener jeg det mest dekkende er å benytte begrepet villet egenskade i henhold til ICD-10 ved selvdestruktiv atferd. Dette bør igjen inndeles i henhold til anvendt metode. Ved sel vpåført forgiftning bør også midlene klassifiseres. Ved kutt bør stedet angis. Endelig bør det foretas en inndeling etter intensjon der man skiller mellom selvmordsforsøk og mer appell pregede handlinger. Begrepet parasuicid viser ved sin lange definisjon at det er upresist med hensyn til flere viktige kliniske begreper.

\section{Referanser}

Ekeberg $\varnothing$, Ellingsen $\emptyset$, Jacobsen D. M ortality and causes of death in a 10-year follow-up of patients treated for self-poisonings in $\mathbf{0}$ slo. Suicide Life Threat Behav 1994; 24: 398-405.

H awton K, Catalan J. A ttempted Suicide. A Practical $\mathbf{G}$ uide to its $\mathbf{N}$ ature and $M$ anagement 2nd ed. Oxford: O xford U niversity Press, 1987.

Jacobsen D, Frederichsen PS, Knutsen KM , Sørum $Y, T$ alseth $T, \varnothing$ degaard O R. A Prospective Study of 1212 cases of A cute Poisoning: G eneral E pidemiology. H uman Toxicology 1984; 3 : 93-106.

Kreitman N, Philip A E, G reer S, Bagley CR. Parasuicide. Br J Psychiatry 1969; 115: 746-47.

Platt S, Bille-Brahe, U, Kerkh of A, Schmidtke A Bjerke $T$, C repet $P$, De Leo $D, H$ aring $C$, Lønnqvist J, M ichel K, Philippe, A, Pommereau $X, Q$ uerejeta I, Salander-Renberg $E$, Temesvary $B, W$ asserman $D$, Sampaio Faria J. Parasuicide in Europe: $T$ he WH O/E U RO Multicentre Study on Parasuicide. I. Introduction and preliminary analysis for 1989. A cta Psychiatr Scand 1992; 85: 97-104.

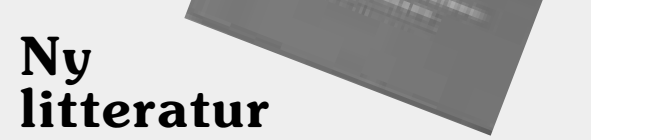

Fleischer E: D en talende taushed. Selvmord og selvmordsforsøg som talehandling.

\section{0 dense: Elene Fleischer og 0 dense} U niversitetsforlag, 2000.

U nder denne tittelelen er Elene Fleischers omredigerte avhandling for den filosofiske doktorgrad utkommet. Elene Fleischer vil være vel kjent også blant norske fagfolk som arbeider inne suicidologi. H un er lektor og har undervist leger og sykepleiere. $\mathrm{H}$ ennes grunnleggende hypotese er at selvmordshandlinger er kommunikasjon og derfor kan oppfattes som en måte å tale på og kan tillegges en mening. H ennes tenkemåte samsvarer meget med Stengelsi omtaler av de tre A -er: appell, aggresjon, ambivalens, og også med Farberow og Shneidmans "cry for help". I bokens første del gjennomgås det teoretiske grunnlag for en analyse av selvmordshandlinger som kommunikative ytringer. I annen del gir Fleischer en analytisk gjennomgang av de åtte kasus som er det empiriske grunnlag $i$ avhandlingen. $V i$ får et godt innblikk i tankegangen hos åtte kvinner som befinner seg på knivseggen mellom liv og død. Elene Fleischer beskriver hvordan det kan være av betydning både for forebygging og behandling at man vurderer selvmordshandlinger også som kommunikasjon shandlinger. Som gammel kliniker kan jeg bare understreke betydningen av det aspektet Fleischer har gått i dybden på. Boken er presentert i smakfull design med illustrasjoner, og de 8 kasuistikker belyser godt viktige aspekter ved suicidal problematikken. Boken fortjener å bli lest av alle med interesse for suicidologi.

\section{Nils Retterstøl}

Retterstøl N . Selvmord. U niversitetsforlaget, 1995.

Rossow I, W ichstrøm L. Parasuicide and use of intoxicants among $\mathrm{N}$ orwegian adolescents. Suicide Life Threat Behav 1994; 24: 174-83.

Øivind E keberg er overlege i psykiatri ved A kuttmedisinsk avd., Divisjon for kirurgi, U llevål sykehus, og professor i medisinske atferdsfag ved U niv. i 0 slo. 